\title{
Research on the Reform of Training English Talents for Event Industry
}

\author{
Jianhua Zhou \\ Tourism College \\ Chongqing University of Arts and Science \\ Chongqing, China 402160
}

\begin{abstract}
With the increasing development of event industry in China, the demands for English talents for event industry are great and urgent. The question of how to promote the rapid growth of these English talents to meet the requirement of internationalized event industry needs a quick and satisfying answer. This paper analyzed the required capabilities for these English talents and discussed the existent problems in training English talents for event industry, based on which the specific advices were proposed.
\end{abstract}

Keywords-English Talents for Event Industry; Capabilities Development; Talents Training

\section{INTRODUCTION}

English talents for events are the crucial components of the developing of event industry. Statistical data show that since the opening up and reform of China, China's industry event has developed in unprecedented scale. Its annual growth rate is $20 \%$ and the economic scale of this industry has gradually increased, making it a new shinning point in developing national economy ${ }^{[1]}$. However, the gaps with developed countries are still big, which are mainly reflected in the developmental level of event industry, determining that the linguistic qualities of most related practitioners are relatively low and that professional English talents particularly for event industry are lacking [2] internationalizing process of event industry in China, the related practitioners are required to not only possess professional knowledge of event and proficient working techniques, but also own the capabilities of expressing and communicating fluently in English.

\section{REQUIREMENTS FOR TRAINING ENGLISH TALENTS FOR EVENT}

\section{A. Good Knowledge of Professional Theories}

Professional knowledge for event includes various aspects, such as management science, HR management, marketing, market survey \& prediction, organizational behavior, statistics and financial management. There are many professional courses for event, including Risk Management at Event, Management of Event Operation, Conference Plan \& Organization, FSE (Festivals \& Special Events) Plan \& Organization, Plan for Incentive Travel and so on. All of these are the knowledge should be mastered by students at major of event management. Besides, they are also required to possess some professional techniques, understand the latest development trends, focus on the social current affairs, expand their international vision and apply their professional knowledge into practice so as to finish tasks.

\section{B. Ability in Fluently Oral Expression}

For English talents for event, ability in fluently oral expression is a necessity. No talent with linguistic barriers shall be hired to communicate with clients. Ability of oral expression involves English and Chinese. Excellent ability in oral expression can make your ideas and intentions understood by your clients quickly, yielding twice the result with half the effort.

\section{Excellent Abilities of Coordinating and Communicating}

Activities at event are quite complicated and involves a wild range of aspects, making them not just simple activity items. During an activity at event, more people and items shall be implicated. At this time, excellent abilities of coordinating and communicating shall lead to getting twofold results with half the effort ${ }^{[4]}$. From the point view of society, good communicating ability, interpersonal relationship and linguistic capability can let you get opportunities which others desire but lack. Therefore, our abilities of coordinating and communicating should be continuously improved to avoid embarrassment and troubles.

\section{EXISTING PROBLEMS FOR TRAINING ENGLISH TALENTS FOR EVENT}

\section{A. Sparse Number of Professional Talents}

With the rapid development of event industry in China, schools for event have been correspondingly increasing. However, the number of professional talents still can't catch up with the market demands. Besides, English talents for event are urgently lacking. At many event activities, there are few English talents who truly understand the knowledge about event, many of whom even couldn't tell the most fundamental professional terms. Besides, other professional vocabularies related with exhibition and event are out of their reach. As number of international conferences and exhibitions held in China is increasing, demands for English talents for event rise. However, it's undeniable that professional talents are wanted. 


\section{B. The Lagged-Behind Training for Professional Talents}

Firstly, the lack of professional teachers. Many teachers for event major don't graduate from school or department for event at the first place. Therefore, the courses of English for event at many colleges or school are taught by teachers from English major who lack a knowledge of event; on the other hand, if the foresaid courses are taught by practitioners of event, although their practical experience is rich, their English levels can't reach the professional standards.

Secondly, unreasonable setting for courses. For the setting of professional courses for event, courses for English for event should be seriously treated as the core ones. At the first and second year at college or university, students should consolidate their fundamental knowledge of English, on the basis of which the English abilities should be combined with professional knowledge for event, which is a process from general to specific.

Thirdly, application-oriented books for English for event are experiencing sparseness. Currently, not only is the quantity of books less than enough, but also these books aren't well combined with English, which seriously negatively affects the quality of training professional talents for event.

\section{Quality of Professional Talents to be Improved}

Most of professional talents for event haven't graduate from event major or lack solid foundations or training, thus showing a lower level of professionalization. At event activities, they operate according to their gained working experience rather than the large background and systematic properties of event, which is badly affecting the professional level of an activity.

\section{ADVICES ON TRAINING ENGLISH TALENTS FOR EVENT}

\section{A. Governmental Guidance and Industrial Regulation}

Government should play the leading role in training professional talents for event. Therefore, these talents should be trained from three aspects, namely policies, industrial association and talents community.

1) Establishing Relevant Policies and Speeding Institutional Construction: In training professional talents, government should reinforce the institutional construction, improve the standardization and transparency of management and establish relevant policies of training talents for event, truly applying the training policies into each individual person and allowing the event practitioners to personally participate in the training process. Meanwhile, various issues should be further identified, such as liable parties and means for management. Unqualified institutions for event training or professional certification training should be regulated to protect the legal rights of enterprises and people so that practitioners can find appropriate posts at a fair market.

2) Exerting Functions of Association and Regulating Industrial Standards: The important roles of industrial association in training professional talents for event industry have been well showed at modern society. When an association periodically organizes relevant activities, calls personnel in event industry together, researches event-related big issues and proposes measures, their autonomy should be fully exerted. The governmental trustworthiness, support for an industry and social approval degree should be improved. After the establishment of this association, the government should return the functions (e.g. performing industrial statistics and evaluating an event) originally held by industrial association to them for a better displaying of autonomy. Association of event industry should fully employ their own advantages, providing qualified professional talents, establish quality certification, regulate the certification authority inside the industry and purify the environment of market.

3) Strengthening Team Building and Introducing Urgently Needed Talents: Firstly, relevant policies and regulations about developing team of talents for event industry should be established. The current conditions of English talents for event should be surveyed, analyzed and studied to make the corresponding outlines and overall arrangements for the development of a team of highlyqualified talents for event. The necessity of training English talents for event should be guaranteed from the institutional perspective. Then, the right judgements and reasonable solutions should be proposed and obtained after actual survey and analysis. Secondly, education and training for English talents for event should be quickened. The existing methods, forms and other details of training professional talents in event industry should be known and the training of these talents should be seriously treated. Besides, the standardized educational mechanism should be formed. Colleges and universes should be encouraged to set up major of event and open English courses for event, thus improving the educational levels and training highly qualified talents. Eventually, highly qualified talents of event should be introduced. Senior English talents for event should be invited both at home and abroad. They should possess international vision and practical experience and get themselves dedicated to the advancement of event industry, which shall further promote the training of English talents for event.

\section{B. Building Up Teaching-Staff Strength and Innovative Courses}

1) Improving Quality of Teaching and Broadening Teaching Space. Since information and knowledge are directly received at classroom, the quality of teaching is crucial. When it comes to the current courses of English for event, in most cases only the most superficial contents at books are taught to students who shall forget everything they learn at class very soon. Therefore, the quality of teaching should be improved greatly. Professional English for event is a fairly professional subject, with comprehensive and crossculture features ${ }^{[5]}$. While teaching at classroom, teacher should infuse the English contents required by students at event major into professional knowledge, allowing their English capabilities to support their practical abilities and performance in professional filed.

Reform methods of teaching and reinforce planning and training for teachers. Teachers should be required to receive training or further education periodically and annually. They should dig deep into the event industry, actually understand the talents required by this industry, realize the capabilities and qualities urgently needed and further improve the levels of teaching of teachers ${ }^{[6]}$. Besides, colleges or universities can actively introduce industrial experts and directors of event 
enterprises to come to school for lecturing so that students can directly get in touch with the industrial personnel, which can promote the talents-training process. The improvement of quality of teaching is closely correlated with the hardware equipment. Increasing the input of hardware equipment can improve the environment for teaching. Hardware equipment including multi-media devices and room for practical training can fully motivate the student and get them all participated in and create the free and positive atmosphere.

2) Optimizing Curriculum System and Scientifically Compiling Textbooks: At first, textbooks should focus on improving students' communicative competence, and infuse abilities of oral expression, random conversation and internationally cultural knowledge to build up students' comprehensive capabilities of application. Secondly, the choosing of textbooks should correspond with the features of internationalization and trends of times and broaden students' international visions. Besides, in the process of teaching and learning, students' initiative should be given full play. More autonomy should be granted to students. CDs or international websites should be provided so as to keep pace with times.

3) Emphasizing Practice Outside School and Promoting Cooperation Between School and Enterprises: The major of event is companied with a large amount of applications and the practical experience is welcomed and emphasized by enterprises. In the process of talent training, more opportunities of applications should be created for students. Firstly, environment situated for English application for event can be simulated for English communication just like at a real event. Students can participate in the whole process of project beginning to ending. Though this way, students' practical experience shall be increased. Secondly, students should go out of campus and enter into the real society, participate in the real event activities as a working staff or volunteers. They can directly work the event procedures and hone their skills. Additionally, they can take part in every sort of business activities, get themselves familiar with rules of international trade, skills for business negotiation and translating tasks.

\section{Oral Communication, Learning for Practice}

1) Building Up Learning Capabilities and Reinforcing Training for Oral Expression:Students at major of event should possess excellent abilities of learning, reading, language studying, logical thinking and independent learning. They should boast a wide range of knowledge and compressive abilities [7]. Every day, students should try to reinforce the training of oral English by listening radio, reading English articles, reviewing English website for event and watching English movies for the further improvement of their English level.

2) Improving Communicative Abilities and Advancing Comprehensive Qualities: Wonderful abilities of coordinating and communicating can make complicated things easier. Therefore, besides learning abilities, English talents for event should also improve their capabilities of coordinating, innovating, organizing and oral expression, being a person with passion, vitality and good temperament.

3) Paying Close Attention to Current Affairs and Broadening International Vision: Event industry has distinct features of times. The innovative points of event activities can come from everything from the society. An English talent for event should pay close attention to current affairs and have their own opinions and views. They can read magazines, newspapers or know the latest news through Web. They should timely know the newest information for international conferences and exhibitions and develop their senses for the industry.

\section{CONCLUSION}

With the internationalization levels of event industry in China, the event practitioners are required to possess excellent capabilities of English expression, verbal and professional communication, and provide each sort of international event activities with highly-qualified and high level services. Government, schools and individuals should reform from various aspects and actually apply each policies to achieve the goals and promote the internationalization process of event industry in China.

\section{REFERENCES}

[1] Xu Lin, Qiao Xianghong; Discussion of Reforming Patterns of Training Professional English Talents for Event $[\mathrm{J}]$; Science and Education Magazine, 2009(09):47-48.

[2] Zhang Cuijuan; Research on Influences of Event Industry on Development of Regional Economy[J]. Academic Exchange, 2014(05):89-92.

[3] Zhao Lu; Discussion on Features of English for Event and Systems of Training Professional Talents[J]. Journal of Hubei University for Correspondence, 2011(08): 142-143.

[4] Zhao Fang; Research on Infiltration Modes of Training Cross-Culture Communicative Capabilities[D]. Shanghai: Shanghai International Studies University, 2014.

[5] He Ronghui. Several Advices on Constructing Systems for Teaching English For Event[J]. World of Entrepreneurs, 2010(09):82-83.

[6] Zhou Ziyu; Preliminary Exploration in Courses of Teaching English for Event Based on the Integration of Work and Study[J]. Occupation, 2012(18):60-61.2013(03):18-19.

[7] Xu Jianhua; Some Ideas about Measures of Training English Talents for Event at Schools of Higher Vocational Education at Guangdong Province $[\mathrm{J}]$. Journal of Hubei University for Correspondence, 2013(03):18-19. 